\title{
PEMBAGIAN HAK WARIS ATAS PERGANTIAN JENIS KELAMIN
}

\author{
Oleh : \\ R. Hari Purwanto*, Eddy Herwanto* \\ *Fakultas Hukum Universitas Gresik
}

\begin{abstract}
Abstrak
Operasi perbaikan atau penyempurnaan jenis kelamin yang dilakukan orang-orang yang mempunyai kelainan pada alat kelaminnya, atau mempunyai kelamin ganda atau dapat disebut Khuntsa, maka berdasarkan hukum Islam dan penetapan Fatwa MUI Musyawarah Nasional II Tahun 1980 dan Fatwa MUI No.03/MUNASVIII/2010 Tentang pergantian dan Penyempurnaan Kelamin dan Keputusan Muktamar Nahdatul Ulama ke-26 di Semarang pada tanggal 10-16 Rajab 1399/511 Juni 1979 M, Memutuskan Hukumnya boleh, Ketentuan tersebut merupakan Tafsiran Hadist Nabi Muhammad S.A.W. (HR.Ahmad), sedangkan seseorang yang normal kelaminnya dilarang melakukan pergantian jenis kelamin karena menentang kodrat Allah S.W.T yang telah menentukan atas dirinya. Disisi lain akibat dari pergantian jenis kelamin nanti akan berpengaruh pula terhadap ; hak kewarisannya.
\end{abstract}

\section{Kata Kunci : Hak Waris}

Operation of repairs or refinements of sex carried out by people who have abnormalities in their black instruments or have multiple genitals or can be called khuntsa, then based on islamic law and the determination of fatwa MUI National conference II year 1980 and fatwa MUI No.03/MUNAS-VIII/2010 concering the replacement and refinement of genitals and the ulema in semarang on 10-16 rajab 1399/5-11 june 1979, deciding that the law is permissible, the provision is an interpretation of the hadith of the prophet Muhammad (HR.Ahmad), while someone whose normal sex is forbidden to change sex because it opposes the nature of Allah S.W.T who has determined on him. Other positions resulting from the change of sex will also affect the ; right to inheritance.

\section{Keywords : Inheritance rights}

\section{A. PENDAHULUAN}

Lahir, hidup dan meninggal dunia adalah hal yang pasti terjadi dan dialami oleh setiap Manusia. Kehidupan yang dijalani Manusia, sebagian ada yang mampu mengumpulkan harta yang banyak dan sebagian lagi ada yang sebaliknya. Setelah tiba kematiannya, maka apa yang didapatkannya dan dimiliki selama hidupnya tersebut akan ditinggalkan dan menjadi hak para Ahli Waris yang memang berhak menerimanya. Hukum Kewarisan memegang peranan yang sangat penting. Sebab merupakan sesuatu yang erat kaitannya dengan ruang lingkup kehidupan Manusia karena setiap Manusia yang hidup akan mengalami 
peristiwa hukum yang lazim disebut dengan kematian. Masalah kewarisan dalam hukum Islam merupakan hal yang penting, karena menyangkut segala sesuatu yang ditinggalkan oleh seseorang yang meninggal dunia, baik berupa harta benda maupun hak-hak kebendaan. Mengingat pentingnya masalah kewarisan ini, maka Allah S.W.T menetapkan aturannya secara terang dan tegas dalam Al-Qur'an. Penetapan ini bertujuan untuk memberikan kepastian hukum terhadap hak milik seseorang dengan cara seadil-adilnya ${ }^{1}$.

Berdasarkan Pasal 1 ayat (3) Undang-Undang Dasar Tahun 1945, “ Negara Indonesia adalah Negara Hukum ", menyatakan salah satu tujuan Negara Indonesia adalah membentuk suatu pemerintahan Negara Indonesia yang melindungi segenap Bangsa Indonesia dan seluruh tumpah darah Indonesia. Penegasan dalam Pembukaan UUD 1945 Alinea Ke IV merupakan bagian dari upaya untuk mencapai tujuan Nasional, isu tentang Hak Asasi Manusia tidak dilepaskan dari Negara yang berkonsep Negara Hukum. Pemenuhan akan terselenggaranya perlindungan dan penegakan Hak Asasi Manusia menjadi salah satu fokus utama sebuah Negara yang menyematkan diri sebagai Negara Hukum. Negara yang menyematkan dirinya sebagai Negara Hukum wajib menegakkan Hak Asasi Manusia sebagai salah satu syarat bagi Negara Hukum itu sendiri. HAM muncul dari keyakinan manusia itu sendiri bahwasannya Manusia selaku Makhluk ciptaan Tuhan adalah sama derajatnya, atas

1 Hazairin, Hukum Kewarisan Bilateral Menurut Al-Qur'an dan Hadist, Tinta Mas, jakarta 1993,hlm.9. dasar itulah Manusia harus diperlakukan secara sama adil dan beradab. Hak Asasi Manusia bersifat universal artinya berlaku untuk semua Manusia tanpa membedabedakan berdasarkan atas Ras, Agama, Golongan, Suku dan Bangsa. Mengenai pengaturan Hak Asasi Manusia di Negara Indonesia dapat dilihat pada perubahan kedua UUD 1945 Tahun 2000 yakni di Bab XA tentang Hak Asasi Manusia mulai dari pasal 28 A sampai dengan $28 \mathrm{~J}$, sebagaimana ditegaskan pada Pasal 28 A yang mengatur bahwa :

" Setiap Orang berhak untuk hidup serta berhak mempertahankan hidup serta mempertahankan hidup dan kehidupanya "

Hak Asasi Manusia adalah Hakhak yang dipunyai oleh semua orang sesuai dengan kondisi yang Manusiawi, sehingga HAM tidak terlepas dari jenis kelamin seseorang yakni laki-laki dan perempuan baik menjalankan kehidupan sehari-hari. Namun ternyata ada beberapa Manusia yang diberikan keistimewaan oleh Tuhan Yang Maha Esa dimana mereka diberikan kelebihan dalam jumlah kelamin atau bisa disebut dengan kelamin ganda (Ambiguos Genetalia) ${ }^{2}$.

Ambiguos Genetalia atau kelamin ganda adalah suatu jenis langka dimana alat kelamin bayi yang tidak jelas sebagai alat kelamin laki-laki atau perempuan. Pada penderita kelamin ganda alat kelamin tidak tumbuh sempurna, alat kelamin yang ada diluar tubuh tidak mungkin sama dengan yang didalam tubuh. Misalkan, meskipun diluar seperti alat kelamin perempuan, namun tubuh bagian dalam tidak

2 Siti Fikriyah, Hak Asasi Manusia Kewarganegaraan dan konstitusi, Nbel Edumedia, Jakarta, 2008, hlm. 15. 
mempunyai rahim atau induk telur. Dalam Islam kelamin ganda dikenal dengan istilah Khuntsa, Kasus tentang penderita kelamin ganda atau Ambiguous Genetalia pernah terjadi dibeberapa di Indonesia. Kasus penderita kelamin ganda yang dialami oleh Muhammad Prawiro Dijoyo, 23 Tahun yang bertempat tinggal di kabupaten Semarang. Dia pernah menjadi mantan penderita kelamin ganda yang terlahir dengan nama Siti Maemunah. Pada dirinya, kelaminnya yang berbentuk seperti perempuan tidak diikuti dengan perubahan fisik, sehingga Muhammad Prawiro Dijoyo memeriksakan diri. Hasil pemeriksaan molekular dan sitogenetika kedokteran kromosom Siti Maemunah adalah 46 XY artinya dia adalah laki-laki, begitu pula dengan pemeriksaan testoteronnya adalah 1.36 yang artinya diatas testoteron perempuan yang biasanya antara 0,1 sampai dengan 0,9 . Kasus serupa pun sama yang dialami oleh Supriyanti sekarang menjadi nama Bagus Supriyanto terjadi pada tahun 2013. Supriyanti alias Bagus Supriyanto dilahirkan dengan memiliki kelainan pada alat kelaminnya, namun didaftarkan ke catatan sipil bahwa dia adalah seorang perempuan, setelah beranjak dewasa, Supriyanti alias Bagus Supriyanto tidak memiliki tandatanda fisik sebagai perempuan, namun lebih cenderung sebagai seorang laki-laki, pemeriksaan pada tahun 2004 oleh dokter yang memeriksanya mengambil contoh testisnya ternyata mempunyai kromosom menunjukkan $46 \mathrm{XY}$, kemudian melakukan tes hormon hasilnya testoteronnya tinggi 1053 ng/dl menunjukkan $100 \%$ generalnya laki-laki. Sehingga dokter mengambil kesimpulan bahwa Supriyanti alias Bagus Supriyanto adalah laki-laki ${ }^{3}$.

Kepastian hukum sangatlah penting agar dapat dijadikan rujukan bersama pada hukum yang satu, senada dengan pendapat diatas M.Yahya Harahap menyatakan bahwa penyusunan Kompilasi Hukum Islam (K.H.I) adalah untuk mempositifkan Hukum Islam di Indonesia, agar dijadikan pedoman oleh para Hakim dalam melaksanakan tugasnya sehingga terjamin adanya kesatuan dan kepastian hukum. Sebab untuk dapat berlakunya hukum Islam di Indonesia, harus ada antara lain Hukum yang jelas dan dapat dilaksanakan oleh aparat penegak hukum. Kompilasi Hukum Islam sebagai sumber Hukum Positif bagi umat Islam merupakan bukti dari hukum yang hidup di masyarakat Indonesia. Kenyataan pula bagi Hakim dalam Hukum Islam, jika ada kasus yang dihadapinya belum ada Hukumnya, maka ia wajib berljtihd ${ }^{4}$.

Tujuan Ijtihad sebenarnya agar suatu Hukum itu selalu Progresif terhadap kehidupan Masyarakat. Boleh jadi K.H.I sesuai pula dimaksud dengan Undang-Undang Nomor 48 Tahun 2009 maupun 229 Pasal di K.H.I tidak lain agar hukum itu selalu Progresif sesuai dengan nilai keadilan masyarakat, pro rakyat, dan ingin selalu membela

3 MuFlika Nur Hajar Aswad, Siti Maemnah lega kini dipanggil Dijoyo, http : edisi cetak. Joglo sema.co/berita sitimaemunah,diakses pada 23 januari 2016, diunduh di gresik 17 november 2018, 10.25 wib. Hlm.5.

${ }^{4}$ M. Yahya Harahap, Informasi materi K.H.I, mempositifkan Abstraksi Hukum Islam dalam mimbar Hukum : aktualisasi Hukum Islam, Al Hikmah no.5, jakarta, 1992, hlm 25 
kepentingan masyarakat dan berhati nurani.

Istilah Ijtihad dapat diterjemahkan dengan (Rchtsviting Law), yaitu dengan metode istimbath hukum (metode penemuan Hukum) termasuk mengambil presenden hukum yang hidup dalam masyarakat (Living Law), hal tersebut seperti yang dikemukan oleh Peter Mahmud Marzuki yang menyatakan bahwa hakim harus melakukan pembentukan hukum (rechtsvorming) kegiatan-kegiatan semacam itu dalam hukum kontinental disebut sebagai penemuan hukum (rechsvinding) ${ }^{5}$.

Penemuan Hukum harus selalu didasarkan dengan doktrin pembentukan hukum bahwa hanya akan efektif apabila searah dengan hukum yang hidup dalam masyarakat ungkapan lain adalah bermanfaat (maslahat) bagi masyarakat ${ }^{6}$.

Adapun Latar belakang masalah, Bagaimana kedudukan hukum ahli waris yang berganti jenis kelamin dalam pembagian hak waris menurut hukum Islam, dan bagaimana pembagiannya hak waris atas pergantian jenis kelamin menurut Hukum Islam. dengan tujuan penelitian untuk mengetahui kedudukan hukum ahli waris yang berganti jenis kelamin dalam pembagian hak waris menurut hukum Islam, dan untuk mengetahui pembagian hak waris atas pergantian jenis kelamin menurut hukum Islam. Maka penulis akan membahasnya lebih lanjut dalam penulisan dengan

\footnotetext{
${ }^{5}$ Ibrahim Husein, Fiqh Perbandingan Masalah Pernikahan, Pustaka firdaus, Jakarta, 2003, hlm.15-16.

${ }^{6}$ Peter Mahmud Marzuki, Pengantar Ilmu Hukum, Cet 1, Kencana Prenada Media, Jakarta, 2008, hlm.333.
}

judul " Pembagian hak waris atas pergantian jenis kelamin ".

\section{B. METODE PENELITIAN}

Di dalam Penelitian ini, penulis menggunakan metode penelitian yuridis normatif yaitu dilakukan dengan menelah teori-teori hukum, konsep-konsep hukum, asas-asas hukum serta mengkaji peraturan peundang-undangan yang berhubungan dengan pokok permasalahan yang telah dirumuskan dalam penelitian ini. Untuk mencari jawaban atas pokok permasalahan dalam penelitian ini, penulis menggunakan 5 (lima) pendekatan masalah, yaitu pendekatan Konseptual (Conseptual approach), Pendekatan Kasus (case Approach), Pendekatan Perundang-Undangan (Statute Approach), Pendekatan Historis (Historical Approach), dan pendekatan Perbandingan (Comparative Approach).

\section{PEMBAHASAN \\ 1. Pengertian Khuntsa}

Khuntsa adalah seseorang yang mempunyai dua alat kelamin, disamping ia mempunyai penis atau zakar ia juga mempunyai vagina atau farji.

Khuntsa ini banyak dibicarakan dalam kitab-kitab fiqh karena dalam kenyataannya memang sering terjadi, sedangkan hukum dalam keadaan tertentu memisahkan antara laki-laki, urusan menjadi saksi, kewarisan dan lain-lain yang dibedakan padanya lak-laki dan perempuan.

Arti khuntsa menurut bahasa (etimologi) istilah khuntsa berasal dari bahasa Arab Khanatsa yang berarti lunak atau melunak Ibnu Manzhur alam kamus lisan Al-Arab mengatakan

“ Khuntsa adalah orang yang memiliki sekaligus apa yang dimiliki oleh laki-laki atau perempuan " Ibnu 
Manzhur juga mengatakan " Khuntsa adalah orang yang tidak murni (sempurna) sebagai laki-laki atau perempuan. Khuntsa menurut Istilah (terminologi) Sayid Sabiq dalam kitab Fiqh Al-Sunnah mengatakan “ Khuntsa adalah orang yang tidak jelas keadaan dirinya dan tidak diketahui apakah dia laki-laki atau perempuan, karena dia sama sekali tidak memiliki kelamin baik laki-laki maupun perempuan “.

Dan menurut Ensiklopedia Hukum Islam, khuntsa adalah seorang yang diragukan jenis kelaminnya apakah laki-laki atau perempuan karena memiliki alat kelamin secara bersamaan atau pun tidak memiliki alat kelamin sama sekali, baik alat kelamin laki-laki atau perempuan.

Menurut Fuqaha, khuntsa terbagi menjadi dua macam yaitu : Khuntsa Ghairu Musykil (Khuntsa yang tidak sulit atau jelas) yaitu Khuntsa yang telah dapat dihukumi laki-laki atau perempuan dengan memperhatikan tanda-tandanya adalah kepada alat kelamin itu sendiri maupun sifat-sifatnya, apakah mirip kepada perempuan atau lakilaki.

Amir Syarifuddin mengatakan bahwa khuntsa Ghairu Musykil adalah Khuntsa yang melalui alat kelamin yang ada dapat dipastikan jenis kelaminnya. Bila melalui tanda yang ada dipastikan ia laki-laki, maka alat kelamin yang satu lagi disebut alat kelamin tambahan, begitu pula sebaliknya. Khuntsa Musykil (khuntsa yang sulit ditentukan) adalah manusia yang dalam bentuk tubuhnya ada keganjilan, tidak dapat diketahui apakah dia laki-laki atau perempuan, karena tidak ada tanda-tanda yang menunjukkan kelakianya atau samar- samar tanda-tanda itu dan tidak dapat ditarjibkan. Menurut Wahbah Zuhaili, khuntsa musykil adalah orang yang keadaanya sulit ditentukan, tidak diketahui kelakianya atau perempuannya, seperti dia kencing dari alat laki-laki dan perempuan atau tampak jenggot dan payudara dalam waktu yang sama, dengan kemajuan ilmu dan teknologi kedokteran modern khuntsa musykil dapat diperiksa dengan ilmu dan peralatan kedokteran, apakah mereka memiliki sperma atau ovum ${ }^{7}$.

Sehubungan dengan ini pula, dalam kamus besar bahasa indonesia departement pendidikan dan kebudayaan menyebutkan sebagai berikut :

Banci adalah manusia yang bersifat laki-laki dan perempuan tidak lakilaki dan tidak perempuan), banci adalah laki-laki yang bertingkah laku dan berpakaian sebagai perempuan dan sebaliknya, wadam, waria ${ }^{8}$.

Musyawarah Nasional (MUNAS) VIII Majelis Ulama Indonesia memandang perlu menetapkan fatwa tentang Perubahan dan Penyempurnaan jenis Kelamin agar menjadi pedoman masyarakat Muslim di Indonesia.

Maka Dewan Majelis Ulama Indonesia No.03/MUNAS-VIII/2010 mengeluarkan ketetapan yang berisi sebagai berikut :

A. Penggantian Alat Kelamin.

7 Marisa Arsiwi Diningtria Sistem Kewarisan khuntsa (kelamin ganda)menurut Hukum Waris Islam digilib.unila.ac.id diakses 20 juni 2017, diunduh gresik 24 Januari 1019, 17.25 wib

8 Departement Pendidikan dan kebudayaan, Kamus Besar Bahasa Indonesia, Cet.2, Jakarta: Balai Pustaka,1989 hlm.74. 
1. Mengubah alat kelamin dari laki-laki menjadi perempuan atau sebaliknya, yang dilakukan dengan sengaja, misalnya dengan operasi ganti kelamin, hukumnya haram. ;

2. Membantu melakukan ganti kelamin sebagaimana point 1 hukumnya haram. ;

3. Penetapan keabsahan status jenis kelamin akibat operasi penggantian alat kelamin sebagaimana point 1 tidak diperbolehkan dan tidak memiliki implikasi hukum syar'i terkait dengan pergantian tersebut. ; dan

4. Kedudukan hukum jenis kelamin orang yang telah melakukan operasi ganti kelamin sebagaimana point 1 adalah sama dengan jenis kelamin dia semula seperti sebelum dilakukan operasi ganti kelamin, meski telah memperoleh penetapan pengadilan.

B. Penyempurnaan

Alat

Kelamin.

1. Penyempurnaan alat kelamin bagi seorang khuntsa yang fungsi alat kelamin laki-lakinya lebih dominan atau sebaliknya, melalui operasi penyempurnaan alat kelamin hukumnya boleh.;

2. Membantu melakukan penyempurnaan alat kelamin sebagaimana dimaksud pada point 1 hukumnya boleh.;

3. Pelaksanaan operasi penyempurnaan alat kelamin sebagaimana dimaksud point 1 harus didasarkan atas pertimbangan medis, bukan hanya pertimbangan psikis semata.;

4. Penetapan keabsahan status jenis kelamin akibat operasi alat kelamin sebagaimana dimaksud pada point 1 dibolehkan, sehingga memiliki implikasi hukum syar'i terkait dengan penyempurnaan tersebut.; dan

5. Kedudukan hukum jenis kelamin orang yang telah melakukan operasi penyempurnaan alat kelamin sebagamana dimaksud pada poin 1 adalah sesuai dengan jenis kelamin setelah penyempurnaan sekalipun belum memperoleh penetapan pengadilan terkait perubahan status tersebut ${ }^{9}$.

\section{Pengertian Waris}

Waris menurut bahasa ialah Berpindahnya sesuatu dari seseorang kepada orang lain, atau dari suatu kaum kepada kaum lain. Adapun makna istilah yang dikenal para ulama ialah berpindahnya hak

${ }^{9}$ https://nasional.kompas.com> MUI Haramkan Perubahan dan Penyempurnaan Kelamin-Nasional Kompas diakses selasa 27 juli 2010, diunduh di gresik 10 juli 2019, 22.04 wib. 
kepemilikan dari orang yang meninggal kepada ahli warisnya yang masih hidup, baik yang ditinggalkan itu berupa harta bergerak (uang), harta tidak bergerak (tanah), atau apa saja yang berupa hak-hak legal secara syar'i.

Dalam Kompilasi Hukum Islam (K.H.I), Hukum kewarisan adalah hukum yang mengatur tentang pemindahan hak pemilikan harta peninggalan (tirkah) pewaris, menentukan siapa-siapa yang berhak menjadi ahli waris dan berapa bagiannya masing-masing. Di dalam Definisi Hukum Waris Islam, Kata mewaris berasal dari bahasa arab yakni mirats, bentuk jamaknya adalah mewaris yang berarti harta peninggalan orang yang meninggal, dan hendak dibagikan kepada ahli warisnya ${ }^{10}$.

\section{Pengertian Ahli Waris}

Definisi Ahli waris adalah orang-orang yang karena sebab keturunan, perkawinan berhak menerima atau mendapatkan bagian dari harta orang yang meninggal dunia. Dan didalam Kompilasi Hukum Islam Pasal 171, Pasal 172, Pasal 174. Ahli Waris adalah orang yang pada saat meninggal dunia mempunyai hubungan darah atau hubungan perkawinan dengan pewaris, beragama Islam dan tidak terhalang karena hukum untuk menjadi ahli waris. Kelompok-kelompok ahli waris terdiri dari : menurut hubungan darah : golongan laki-laki terdiri dari : ayah, anak laki-laki, saudara lakilaki, paman dan kakek, dan golongan perempuan terdiri dari : ibu, anak perempuan, saudara perempuan dan nenek, menurut hubungan

${ }^{10}$ Tinuk Dwi Cahyani, Hukum Waris Dalam Islam, Umm Pres, Malang, 2018, hlm.9-16. perkawinan terdiri dari duda atau janda, apabila semua ahli waris ada maka yang berhak mendapat warisan hanya anak, ayah, ibu, duda atau janda $^{11}$.

\section{Dasar Hukum Kewarisan Islam}

Dasar dan sumber utama dari Hukum kewarisan Islam sebagai hukum agama Islam adalah nash atau teks yang terdapat dalam Al-Qur'an Hadist dan Ijtihad. Didalam AlQur'an persoalan Hukum Kewarisan Islam diatur dalam beberapa surah Yaitu :

1. QS. An-Nisa' (4) : 7

"Bagi orang laki-laki ada hak bagian dari harta peninggalan ibu-bapak dan kerabatnya, dan bagi orang wanita ada hak bagian (pula) dari harta peninggalan ibu-bapak dan kerabatnya, baik sedikit atau banyak menurut bagian yang telah ditetapkan ".

Dasar hukum kewarisan yang kedua, yaitu dasar hukum yang terdapat dalam Hadist Nabi Muhammad S.A.W, sebagai berikut :

1. Hadis Nabi dari Abdullah Ibnu Abbas yang diriwayatkan oleh Imam Bukhari : " Berikanlah Faraidh (bagian yang ditentukan) itu kepada yang berhak dan selebihnya berikanlah kepada laki-laki dari keturunan laki-laki terdekat "

2. Hadis dari Surahbil menurut riwayat kelompok perawi hadis selain imam Muslim : " Dari Huzail bin Surahbil berkata : "Abu Musa ditanya tentang kasus kewarisan

${ }^{11}$ Kompilan Hukum Islam , Buku II Hukum kewarisan Bab I pasal 171, Bab II pasal 172 dan pasal 174 
seorang anak perempuan, anak perempuan dari anak laki-laki dan seorang saudara perempuan. Abu Musa berkata : " Untuk anak perempuan setengah, untuk saudara perempuan setengah. Datanglah kepada Ibnu Mas'ud, tentu ia akan mengatakan seperti itu juga. Saya menetapkan berdasarkan apa yang telah ditetapkan oleh Nabi yaitu untuk anak perempuan setengah, untuk cucu perempuan seperenam, sebagai pelengkap dua pertiga, sisanya untuk saudara perempuan $^{12}$.

\section{Asas Hukum Kewarisan Islam}

Hukum Kewarisan Islam Faraidh adalah salah satu bagian dari keseluruhan hukum Islam yang mengatur peralihan harta dari orang yang telah meninggal dunia kepada orang (keluarga) yang masih hidup. Hukum Kewarisan Islam mengandung berbagai asas yang memperlihatkan bentuk karakteristik dari hukum kewarisan Islam itu sendiri. Asas-asas kewarisan Islam tersebut antara lain :

1. Asas Ijabri

Asas Ijbari yang terdapat dalam hukum kewarisan Islam mengandung arti bahwa peralihan harta seseorang yang meninggal dunia kepada ahli warisnya berlaku dengan sendirinya menurut ketetapan Allah tanpa digantungkan kepada

12 Moh. Muhibbin dan Abdul wahid, Hukum Kewarisan Islam sebagai pembaharuan hukum positif di indonesia, Sinar grafika, Jakarta, 2017, hlm. 13-20. kehendak pewaris atau ahli waris.

2. Asas Bilateral

Asas Bilateral dalam hukum

Kewarisan Islam

mengandung arti bahwa harta warisan beralih kepada ahli warisnya melalui dua arah (dua belah pihak). Hal ini berarti bahwa setiap orang menerima hak kewarisan dari kedua belah pihak garis kerabat, yaitu pihak kerabat garis keturunan laki-laki dan pihak kerabat garis keturunan perempuan.

3. Asas Induvidual

Hukum Islam mengajarkan asas Kewarisan secara individual, dalam arti harta warisan dapat dibagi-bagi pada masing-masing ahli waris untuk dimiliki secara perorangan.

4. Asas Keadilan Berimbang Kata ' Adil ' merupakan kata bahasa Indonesia yang

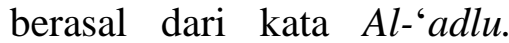
Hubungannya dengan masalah kewarisan, kata tersebut dapat diartikan keseimbangan antara hak dan kewajiban serta keseimbangan antara yang diperoleh dengan keperluan dan kegunaannya.

5. Asas Semata Akibat Kematian

Hukum Islam menetapkan bahwa peralihan harta seseorang kepada orang lain dengan menggunakan istilah kewarisan hanya berlaku setelah yang mempunyai harta meninggal dunia. Asas 
ini berarti bahwa harta seseorang tidak dapat beralih kepada orang lain (keluarga) dengan nama waris selama yang mempunyai harta masih hidup ${ }^{13}$.

\section{Sebab-Sebab mendapatkan Waris}

Menurut Sayid Sabiq, seorang dapat mewarisi harta peninggalan karena Hubungan Kekerabatan (Nasab).

Salah satu sebab dapat beralihnya harta, dari seorang yang telah meninggal dunia kepada orang yang masih hidup adalah dikarenakan adanya hubungan silaturrahim atau kekerabatan antara keduanya, yaitu hubungan nasab yang disebabkan oleh kelahiran. Ditinjau dari garis yang menghubungkan nasab antara yang mewariskan dengan yang mewarisi, dapat digolongkan dalam 3 (tiga) golongan, yaitu sebagai berikut :

A. Furu, yaitu anak turun (cabang dari si meninggal dunia).

B. Ushul, yaitu leluhur (pokok atau asal) yang menyebabkan adanya si yang meninggal dunia.

C. Hawasyi, yaitu keluarga yang dihubungkan dengan si meninggal dunia melalui garis menyamping, seperti saudara, paman, bibi dan anak keturunannya dengan tidak membeda-bedakan laki-laki atau perempuan dunia ${ }^{14}$.

\section{Kedudukan Hukum Hak Waris atas pergantian jenis kelamin}

13 Moh. Muhibbin dan Abdul wahid, Hukum Kewarisan Islam sebagai pembaharuan hukum positif di indonesia, Sinar grafika, Jakarta, 2017, hlm. 24-28.

${ }^{14}$ Aunur Rahim Faqih, Mawaris Hukum Waris Islam,UII Press, Yogyakarta, 2017, hlm. 41-43.
Pada dasarnya di Indonesia sendiri aturan mengenai prosedur pergantian jenis kelamin memang belum diatur secara khusus, akan tetapi untuk memberikan perlindungan, pengakuan, penentuan status pribadi dan status hukum, setiap peristiwa kependudukan dan peristiwa penting yang di alami oleh penduduk warga Negara Indonesia, Negara Indonesia telah menerbitkan Undang-Undang Nomor 23 Tahun 2006 Tentang Administrasi Kependudukan sebagai dasar acuanya.

Adapun Dasar Hukum Yang dituangkan Yaitu :

1. Pasal 77 Undang-Undang Nomor 23 Tahun 2006 Tentang Administrasi Kependudukan berbunyi :

" Tidak seorangpun dapat merubah, mengganti, menambah identitasnya tanpa seizin Pengadilan. Dengan perubahan jenis kelamin tentunya seluruh juga ada perubahan mengenai data kependudukan ".

2. Pasal 3 Ayat (2) UndangUndang Nomor 39 Tahun 1999 Tentang Hak Asasi Manusia berbunyi :

“ Setiap orang berhak atas pengakuan, jaminan, perlindungan dan perlakuan hukum yang adil serta mendapat kepastian hukum dan perlakuan yang sama didepan hukum ".

3. Pasal 17 Undang-Undang Nomor 39 Tahun 1999 Tentang Hak Asasi Manusia berbunyi :

" Setiap orang, tanpa diskriminasi, berhak untuk memperoleh keadilan dengan mengajukan permohonan, 
dan gugatan, baik dalam perkara pidana, perdata, maupun admnistrasi serta diadili melalui proses peradilan yang bebas dan tidak memihak, sesuai dengan hukum acara yang menjamin pemeriksaan yang objektif oleh hakim yang jujur dan adil untuk memperoleh putusan yang adil dan benar ".

4. Hukum Islam

Berdasarkan Musyawarah

Nasional II tahun 1980, Fatwa MUI Nomor : 03/MUNAS-VIII/2010 dan Muktamar Nahdatul Ulama ke-26 di Semarang pada tanggal 10-16 Rajab 1399/511 Juni 1979 M diantaranya memutuskan seseorang lakilaki atau perempuan yang kelamin dalamnya normal, tetapi kelamin luarnya tidak normal, misalnya kelamin luar sama atau cocok dengan kelamin dalamnya, tetapi bentuknya tidak sempurna, lalu dioperasi untuk disempurnakan, hukumnya boleh bahkan lebih utama ketentuan tersebut merupakan tafsiran dari Hadis Nabi Muhammad S.A.W. :

"Berobatlah wahai hambahamba Allah, Karena sesungguhnya Allah tidak mengadakan penyakit kecuali mengadakan pula obatnya, kecuali satu penyakit, yaitu penyakit ketuaan “ (HR.Ahmad) ${ }^{15}$.

${ }^{15}$ Muflika Nur Hajar Aswad, Siti Maemuna lega kini dipanggil Dijoyo, http: edisi cetak. Joglo semar.co/berita sitimaemunah, diakses pada 23 januari 2016,
8. Kajian yuridis putusan Pengadil an Negeri Ungaran Nomor : 518/Pdt.P/2013/PN.Ung

Pemohon telah mengajukan bukti-bukti surat berupa:

1. Foto copy Kartu Tanda Penduduk (KTP) NIK :3322174808900001

tertanggal 22 mei 2008, atas nama : Supriyanti, (diberi tanda P.1)

2. Asli surat keterangan kelahiran, Nomor : 474.1/18 tertanggal 12 juni 2013, atas nama Bagus Supriyanto, (diberi tanda P.2)

3. Foto copy surat keterangan dari dinas kependudukan dan pencatatan sipil kabupaten semarang Nomor : 474.1/508/2013 tertanggal 4 juni 2013, (diberi tanda P.3)

4. Asli surat keterangan pengantar dari Kepala desa Kaliwungu, Kecamatan Kaliwungu Kabupaten Semarang Nomor : 470/1023 tertanggal 5 juni 2013, (diberi tanda P.4

5. Foto copy Kutipan Akta kelahiran Nomor : 6187/TP/2002 tertanggal 2 juli 2002, atas nama Supryanti (diberi tanda P. 5)

6. Foto copy surat tanda Tamat Belajar Sekolah Dasar (SD) Negeri Kaliwungu 2, Nomor 03 Dd 0539502 tertanggal 23 juni 2003, atas nama Supriyanti, (diberi tanda P.6)

7. Foto copy ijazah Sekolah Menengah Pertama (SMP) tahun ajaran 2005/2006, No.DN-03 DIO797726

diunduh di Gresik 17 november 2018, 10.25 wib, hlm.5. 
tertanggal 26 juni 2006, atas nama Supriyanti (diberi tanda P.7)

8. Foto copy Ijazah Sekolah Menengah Atas prgram studi : Ilmu Pengetahuan Sosial tahun pelajaran 2008/2009, No.DN-03 Ma 0036969 tertanggal 13 juni 2009, atas nama Supriyanti. diberi (tanda P.8)

9. Foto copy Kartu Keluarga, No.3322170502788 tertanggal 08-10-2007, atas nama kepala keluarga Mitro Rejo Sukiyo (diberi tanda P.9)

10. Foto copy Surat Keterangan Pembantu Pegawai Pencatat Perkawinan umat Budha Kabupaten Dati II Semarang, Nomor : 02/P4B/SK/I/1991 tertanggal 12 Januari 1991, atas nama Sukiyo dan Suliyem, (diberi tanda P.10)

11. Foto copy Surat Keterangan dari RSUP Dr. Karyadi Nomor

HK.00.01/I.IV/2506/2012, tertanggal 20 november 2012, atas nama Supriyanti, (diberi tanda P.11).

Saksi Achmad Zulfa Juniarto bekerja di Rumah Sakit Umum Pusat Dokter Karyadi Semarang, pendidikan S.3 dokter spesialis Andrologi, saksi kenal dengan pemohon bernama Supriyanti sejak tahun 2003 ketika saksi bersama tim dokter melakukan pemeriksaan awal yaitu melakukan pemeriksaan testis terhadap pemohon yang mempunyai dua organ kelamin. Setelah melakukan pemeriksaan panjang pada tahun 2004 mengambil contoh testisnya dan ternyata mempunyai kromosom menunjukkan $46 \mathrm{XY}$, kemudian melakukan pemeriksaan hormon hasilnya testoteronnya tinggi $1053 \mathrm{ng} / \mathrm{dl}$ menunjukkan $100 \%$ generalnya laki-laki. Dalam organ telur masih diatas belum turun, kemudian mengambil contoh testisnya dan dari hasil pemeriksaan hasilnya ternyata ada gejala tumor. Pada tahun 2009 dilakukan pengambilan testis yang berada dibagian selangkangan arah perut, setelah diambil testisnya. Pemeriksaan psikiater menunjukkan $100 \%$ hasilnya generalnya laki-laki.

pemeriksaan ditemukan organ telur masih diatas belum turun, kemudian mengambil contoh testisnya dan dari hasil pemeriksaan hasilnya ternyata ada gejala tumor. Pada tahun 2009 dilakukan pengambilan testis yang berada dibagian selangkangan arah perut, setelah diambil testisnya. Pemeriksaan psikiater menunjukkan $100 \%$ hasilnya generalnya laki-laki.

Awalnya pada diri pemohon ada dua organ kelamin penis dan vagina yang hanya ada lobang sedalam $1 \mathrm{~cm}$, sedangkan penisnya sebelum dilakukan terapi panjangnya $4,1 \mathrm{~cm}$, dan setelah dilakukan terapi wanita penisnya menyusut menjadi $3,2 \mathrm{~cm}$, lalu melakukan terapi lakilaki lagi dan penisnya membesar lagi menjadi 4,3 cm. Penis pemohon bisa ereksi tetapi kalau menikah atau kawin $100 \%$ tidak bisa mempunyai keturunan karena testisnya sudah diambil. Hasil pemeriksaan scaning tidak ditemukan organ perempuan dalam dan dari data USG tidak ada kandungan dan induk telur.

Menimbang, bahwa di persidangan pemohon telah mengajukan bukti surat P.1 sampai dengan bukti P.11 serta 5 (lima) orang saksi yaitu saksi Suliyem, saksi Ali qoimun, saksi Ngadiman, 
saksi suharno dan saksi dr Achmad zulfa juniarto.

Menimbang, bahwa berdasarkan keterangan saksi suliyem yang merupakan Ibu kandung pemohon, bahwa pemohon lahir di kampung dengan dibantu oleh bidan desa dan sejak lahir secara fisik tampak berjenis kelamin perempuan dan diberi nama Supriyanti yang telah dikuatkan pula dengan bukti surat P.5.

Menimbang, bahwa menurut keterangan saksi Suliyem, oleh karena perubahan sikap dan perilaku dari pemohon, maka pada tahun 2003 sampai dengan tahun 2011 dilakukan pemeriksaan secara medis di Rumah Sakit Umum Pusat Dokter Karyadi Semarang dan telah pula dilakukan operasi sebanyak 3 kali, hal ini dikuatkan dengan bukti P.11 berupa surat keterangan Nomor : HK.00.01/I.IV/2506/2012 tanggal 20 november 2012 tentang identitas Gender yang ditanda tangani oleh Dr.Bambang Wibowo sp.OG (K), dokter pada rumah sakit umum pusat Kariadi Semarang.

Menimbang, bahwa berdasarkan keterangan saksi Ali Qoinum sebagai guru sekaligus ulama yang menerangkan bahwa dalam hal adanya permohonan perubahan jenis kelamin dalam ajaran Islam diperbolehkan, berdasarkan Keputusan Muktamar Nahdlatul Ulama ke-26 di Semarang pada tanggal 10-16 Rajab 1399 H/5-11 Juni 1979 M diantaranya memutuskan : seseorang laki-laki atau perempuan yang kelamin dalamnya normal, tetapi kelamin luarnya tidak normal, misalnya kelamin luarnya sama atau cocok dengan kelamin dalamnya, tetapi bentuknya tidak sempurna, lalu dioperasi untuk disempurnakan maka hukumnya diperbolehkan.

Menimbang, bahwa dalam Pasal 3 ayat 2 Undang-Undang Nomor 39 tahun 1999 tentang Hak Asasi Manusia, menerangkan bahwa setiap orang berhak atas pengakuan jaminan, perlindungan dan perlakuan hukum yang adil serta mendapat kepastian hukum dan perlakuan yang sama didepan hukum, dan pada Pasal 17 Undang-Undang tersebut menguraikan bahwa setiap orang tanpa diskriminasi, berhak untuk memperoleh keadilan dengan mengajukan permohonan, pengaduan dan gugatan, baik dalam perkara pidana, perdata maupun administrasi serta diadili melalui proses peradilan yang bebas dan tidak memihak, sesuai dengan hukum acara yang menjamin pemeriksaan yang objektif oleh hakim yang jujur dan adil untuk memperoleh putusan yang adil dan benar.

Menimbang, bahwa setelah melalui penilaian dari segi yuridis, medis, agama, dan psikologi diri pemohon, maka permohonan pemohon khususnya mengenai pergantian jenis kelamin dan pergantian nama patutlah dikabulkan, demi rasa keadilan, rasa ketentraman, kenyamanan dan masa depan kehidupan pemohon selanjutnya.

Amar putusan menetapkan

1. Mengabulkan permohonan pemohon

2. Menyatakan menurut hukum, bahwa pemohon yang bernama Supriyanti anak ke enam perempuan dari suami isteri Sukiyo dengan Suliyem lahir di Kabupaten Semarang pada tanggal 8 Agustus 1990, sebagaimana kutipan akta kelahiran Nomor : 6187/TP/2002, yang 
dikeluarkan oleh kepala dinas kependudukan catatan sipil dan ketenagakerjaan kabupaten Semarang tertanggal 2 juli 2002, adalah berjenis kelamin laki-laki.

3. Menyatakan menurut hukum, bahwa nama pemohon yang tertulis dan terbaca Supriyanti perempuan lahir dikabupaten Semarang pada tanggal 8 Agustus 1990 berganti nama menjadi Bagus Supriyanto laki-laki lahir di Semarang pada tanggal 8 Agustus 1990 anak dari pasangan suami istri sukiyo dengan suliyem.

4. Memerintahkan kepada panitera pengadilan negeri kabupaten semarang di unggaran untuk mengirim salinan resmi penetapan ini yang telahmempunyai kekuatan hukum tetap tanpa bermaterai kepada :

- Dinas kependudukan dan pencatatan sipil kabupaten semarang untuk ditulis dan dicatat dalam register yang bersangkutan

5. Menolak permohonan selain dan selebihnya

6. Membebankan biaya yang timbul dalam prmohonan ini kepada pemohon sebesar Rp.196.000,- _seratus sembilan puluh enam ribu rupiah).

Demikian ditetapkan pada hari : kamis, tanggal 25 Juli 2013 oleh Kadarwoko, S.H., M.Hum. Hakim pada Pengadilan Negeri Kabupaten Semarang di Ungaran dan penetapan tersebut pada hari itu juga diucapkan dalam sidang yang terbuka untuk umum oleh Hakim tersebut dibantu oleh Bakir sebagai Panitera Pengganti Pengadilan Negeri
Kabupaten Semarang dengan dihadir oleh Pemohon dan kuasa Hukumnya ${ }^{16}$.

\section{Macam-macam Ahli Waris \\ Dan Bagiannya}

Lafadz fardhu merupakan bentuk mufrod (tunggal) dari furudh, yang dalam istilah fiqih mawaris diartikan dengan " Bagian yang sudah ditentukan jumlahnya untuk waris dari harta peniggalan, baik dengan nash ataupun dengan jalan ijma “

Para Ahli waris dapat dikelompokkan menjadi tiga, yaitu :

1. Ahli waris sababiyah (karena perkawinan)

2. Ahli waris nasabiyah (qarabah, hubungan nasab)

3. Ahli waris wala' (pembebasan hamba sahaya)

Adapun bagian furudhul muqaddarah yang ditetapkan dalam kitabullah Al-Quran dikelompokkan menjadi dua kategori, yakni sebagai berikut :

1. Kategori pertama, terdiri atas bilangan $1 / 2,1 / 4$ dan $1 / 8$ (setengah, seperempat, dan seperdelapan).

2. Kategori kedua, terdiri atas bilangan $2 / 3,1 / 3$, dan $1 / 6$ (dua pertiga, sepertiga, dan seperenam).

Hak-hak atau bagian Ahli waris Dzawil furudh.

1. Dzawil furudh yang berhak menerima setengah (Nishf) Harta.

16 Muflika Nur Hajar Aswad, Siti Maemuna lega kini dipanggil Dijoyo, http: edisi cetak. Joglo semar.co/berita sitimaemunah, diakses pada 23 januari 2016, diunduh di Gresik 17 november 2018, 10.25 wib, hal.5. 
Ahli waris yang berhak menerima bagian $1 / 2$ terdiri atas lima orang, yaitu seorang laki-laki dan empat orang perempuan berikut :

a. Suami, ia akan mendapat $1 / 2$ dengan syarat tidak ada anak (anak laki-laki atau anak laki-laki istrinya yang meninggal itu, baik dari hasil perkawinan

dengannya, maupun dengan laki-laki lain).

b. Anak perempuan, ia mendapat bagian $1 / 2$ dengan syarat : Tidak ada saudara laki-laki yang berhak mewarisi, yaitu anak laki-lakinya orang yang meninggal, Tidak lebih dari seorang perempuan.

2. Dzawul furudh yang berhak menerima seperempat (Rubu') Harta.

Ahli waris yang mempunyai hak menerima bagian $1 / 4$ terdiri atas :

A. Suami, yaitu akan mendapat bagian seperempat apabila isterinya yang meninggal mempunyai anak atau anaknya anak laki-laki, baik dari hasil perkawinanya dengan dia atau dengan suami lain. Dasarnya adalah firman Allah S.W.T. :

" Jika isteri-isterimu mempunyai anak, maka kamu mendapat seperempat bagian dari harta yang ditinggalkannya

Qs.An-Nisa': 12

B. Isteri, ia akan mendapat bagian seperempat apabila suami tidak mempunyai anak atau anaknya anak (cucu) terus kebawah, baik dari isterinya itu atau dari isteri lain.

Dasarnya adalah firman Allah S.W.T :

" Bagi isteri mendapat seperempat dari harta yang ditinggalkan jika kamu tidak mempunyai anak “ Qs.An-Nisa' : 12

3. Dzawul furudh yang berhak menerima seperdelapan

(tsumun) Harta

Seperdelapan merupakan bagian seorang ahli waris dari beberapa ahli waris, yaitu seorang isteri atau lebih, dengan syarat jika oarang yang meninggal dunia mempunyai anak laki-laki atau anaknya anak laki-laki, baik diperoleh dari perkawinannya dengan isteri itu atau dari isteri lain.

Firman Allah S.W.T. :

“ Jika kamu mempunyai anak, maka para isteri memperoleh seperdelapan dari harta yang kamu tinggalkan sesudah dipenuhi wasiat yang kamu buat atau dan sesudah dibayar utangutangnya "Qs-An-Nisa': 12

4. Dzawul furudh yang berhak menerima dua pertiga (tsulutsani) harta.

Ahli waris yang berhak menerima bagian $2 / 3$ terdiri atas empat orang, yang 
semuanya adalah perempuan, yaitu berikut ini :

Dua orang anak perempuan atau lebih, dengan syarat tidak ada anak laki-laki yang menjadikannya sebagai ashabah.

Firman Allah S.W.T. :

"Dan jika anak itu semuanya perempuan lebih dari dua maka bagi mereka dua pertiga dari harta yang ditinggalkan “ Qs.An-Nisa': $11^{17}$.

\section{Pembagian waris Khuntsa}

Para fuqaha berbeda pendapat tentang hukum warisan bagi khuntsa musykil ini.

Berkata Abu Hanifah, “ Sesungguhnya ia diberi bagian sebagaimana bagian laki-laki, kemudian diberi bagian sebagaimana bagian perempuan. Oleh karena itu, dia harus diperlakukan dengan cara yang terbaik dari dua keadaan itu sehingga seandainya ia mewarisi menurut satu keadaan dan tidak mewarisi menurut keadaan lain maka ia tidak diberi sesuatu. Seandainya ia mewarisi menurut dua keadaan dan bagiannya berbeda maka ia diberi yang minimal dari kedua bagian itu ".

Imam Malik, Abu Yusuf, serta golongan Syi'ah Imamiyyah berkata : "Ia mengambil pertengahan antara bagian laki-laki dan bagian perempuan ".

Adapun Imam Syafi' berkata : “ Masing-masing dari ahli waris dan khuntsa diberi yang minimal dari dua keadaan, sebab ia mengecilkan bagian masing-masing “.

Imam Ahmad berkata : " Bila kejelasan si khuntsa ditunggu maka

17 Aunur Rahim Faqih, Mawaris Hukum Waris Islam, UII Press, Yogyakarta, 2017, hlm. 115-123. masing-masing dari khuntsa dan ahli waris mendapatkan bagian terkecil dan sisanya ditangguhkan dulu. Apabila kejelasan urusan khuntsa tidak ditunggu lagi maka ia mengambil pertengahan antara bagian laki-laki dan bagian perempuan ".

Akan tetapi, Undang-Undang Wasiat Mesir mengambil pendapatnya Imam Abu Hanifah, yang termuat dalam Pasal 46 Undang-Undang Waris Mesir Nomor 77 Tahun 1943 yang berbunyi : “ Bagi khuntsa musykil, yaitu orang yang tidak diketahui apakah ia itu laki-laki atau perempuan, mendapatkan bagian yang terkecil dari dua bagian dan sisa harta peninggalan diberikan kepada ahli waris yang lain ".

Pasal tersebut penerapanya lebih mudah dan lebih mendekati ketentuan dari Al-Quran dan kaidah hukum Islam, sebab Al-Quran hanya menyebutkan dua jenis ahli waris, laki-laki dan perempuan, dan kaidah hukum Islam menentukan bahwa apabila terdapat keraguan terhadap sesuatu maka yang harus diambil adalah yang yakin. Adapun yang diragukan adalah bagian yang besar dan yang yakin adalah bagian yang terkecil.

Sandaran yang digunakan untuk menentukan laki-laki atau perempuan dari seorang khuntsa adalah sabda Rasulullah S.A.W. yang disampaikan kepada para sahabat atas pertanyaan seorang sahabat, dikala beliau sedang menimang anak Khuntsa Anshar. Beliau besabda :

" Berikanlah warisan anak khuntsa ini (seperti bagian laki-laki atau peempuan) mengingat dari alat kelamin yang mula pertama 
dipergunakannya untuk berkencing “. (HR.Ibnu Abbas).

Adapun cara yang digunakan untuk mencari saham bagi ahli waris khuntsa musykil tersebut adalah sebagai berikut, seorang pewaris meninggalkan ahli waris anak lakilaki dan anak khuntsa musykil maka : 1. Anak khuntsa musykil diperkirakan laki-laki.

Tabel 11

\begin{tabular}{|l|c|c|l|l|l|}
\hline \multicolumn{1}{|c|}{$\begin{array}{c}\text { Ahli } \\
\text { waris }\end{array}$} & $\begin{array}{c}\text { Bagi } \\
\text { an }\end{array}$ & $\begin{array}{c}\text { Dari } \\
\text { am 2 }\end{array}$ & $\begin{array}{l}\text { Nisbah } \\
\text { am }\end{array}$ & $\begin{array}{l}\text { A } \\
\mathrm{m} \\
\mathrm{ja} \\
\mathrm{mi} \\
\mathrm{ah}\end{array}$ & Saham \\
\hline $\begin{array}{l}\text { Anak } \\
\text { laki-laki }\end{array}$ & $1 / 2$ & $\begin{array}{c}1 / 2 \times 2= \\
1\end{array}$ & $3: 2$ & $\begin{array}{l}2 \times 6 / 3 \\
=4\end{array}$ \\
\hline $\begin{array}{l}\text { Anak } \\
\text { khuntsa }\end{array}$ & $1 / 2$ & $\begin{array}{c}1 / 2 \times 2= \\
1\end{array}$ & $\begin{array}{c}\text { Tabayy } \\
\text { un }\end{array}$ & $\begin{array}{c}3 \times \\
2= \\
6\end{array}$ & $\begin{array}{l}1 \times 6 / 2 \\
=3\end{array}$ \\
\hline
\end{tabular}

2.Anak khuntsa musykil diperkirakan perempuan.

Tabel 12

\begin{tabular}{|l|c|c|c|c|c|}
\hline Ahli waris & $\begin{array}{c}\text { Bagia } \\
\mathrm{n}\end{array}$ & $\begin{array}{c}\text { Dari } \\
\text { am 2 }\end{array}$ & $\begin{array}{c}\text { Nisb } \\
\text { ah } \\
\text { am }\end{array}$ & $\begin{array}{c}\text { Am } \\
\text { jam } \\
\text { i'a } \\
\text { h }\end{array}$ & Saham \\
\hline $\begin{array}{l}\text { Anak laki- } \\
\text { laki }\end{array}$ & $2 / 3$ & $\begin{array}{c}2 / 3 \times 3= \\
2\end{array}$ & $3: 2$ & & $\begin{array}{l}2 \times 6 / 3 \\
=4\end{array}$ \\
\hline $\begin{array}{l}\text { Anak } \\
\text { khuntsa }\end{array}$ & $1 / 3$ & $\begin{array}{c}1 / 3 \times 3= \\
1\end{array}$ & & $\begin{array}{c}3 \times 2 \\
=6\end{array}$ & $\begin{array}{l}1 \times 6 / 3 \\
=2\end{array}$ \\
\hline
\end{tabular}

Dengan demikian, dalam perkiraan lak-laki, anak lakilaki menerima $1 \times 6 / 2=3$ dan anak khuntsa menerima $1 \times 6 / 2=3$, kemudian dalam perkiraan perempuan, anak laki-laki menerima $2 \times 6 / 3=4$ dan anak khuntsa menerima $1 \times 6 / 3=2$. Jadi, bagian yang diberikan kepada ahli waris menurut :

Hanafiyyah, Anak laki-laki $=4$, anak khuntsa $=2$ jumlah 6 tidak ada sisa; Syafi'iyyah, anak laki-laki $=3$, anak khuntsa $=2$ jumlah 5 sisa 1 yang ditahan sampa jelas persoalannya; dan

Malikiyyah, anak laki-laki $3+4 / 2=$ $31 / 2$, anak khuntsa $3+2 / 2=21 / 2$ jumlah 6 tidak ada sisa
Demikian jalan yang ditempuh oleh para ulama faradhiyun dalam menentukan jumlah bagian khuntsa musykil ${ }^{18}$.

\section{KESIMPULAN}

Berdasarkan pembahasan yang terdapat pada Bab sebelumnya dan hasil penelitian yang didapatkan oleh penulis, maka penulis dengan ini memberikan kesimpulan sebagai berikut : Khuntsa yang Kelaminya disempurnakan dalam arti bukan pergantian kelamin (transeksual) dapat mempunyai kedudukan yang sah untuk menjadi ahli waris berdasarkan kelamin baru.

\section{E. DAFTAR BACAAN Literatur Buku}

H.Ali Daud, Hukum Islam, Pengantar Ilmu Hukum Dan Tata Hukum Islam di Indonesia,

Rajawali pers, Jakarta, 1993.

H.Abdurrahman, Kompilasi Hukum Islam Di Indonesia, Akademika Pressindo, Jakarta, 2010.

Cahyani Dwi Tinuk, Hukum Waris Dalam Islam, Penerbit Universitas Muhamm adiyah Malang, 2018.

Faqih Aunur Rahim, Mawaris Hukum Waris Islam, cet. I, UII Pres Jogyakarta, 2017.

Hazairin, Hukum kewarisan Bilateral Menurut Al-Qur'an dan Hadis, Tinta mas, Jakarta, 1982.

Husein Ibrahim, Fiqh Perbandingan Masalah Pernikahan, pustaka Firdaus, Jakarta, 2003.

Harahap Yahya, Informasi Materi KHI, Mempositifkan Abstraksi Hukum Islam dalam mimbar hukum; aktualisasi Hukum Islam, No. 5, Al Hikmah, Jakarta, 1992.

18 Moh. Muhibbin dan Abdul wahid, Hukum Kewarisan Islam sebagai pembaharuan hukum positif di indonesia, Sinar grafika, Jakarta, 2017, hlm. 139-147. 
Muhibbin dan Wahid Abdul, Hukum

Kewarisan Islam, Sebagai

Pembaharuan Hukum Positif di

Indonesia, Cet.1, Sinar Grafika,

Jakarta, 2017.

Marzuki Mahmud, Pengantar Ilmu

Hukum, cet.I, Jakarta, Kencana

Prenada Media, 2008.

Siti Fikriyah Ham Kewarganegaraan dan konstitusi, Nobel Edumedia, Jakarta, 2008.

Sarmadi Sukris, Dekonstruksi Hukum Progresif Ahli Waris Pengganti Dalam

Kompilasi Hukum Islam, Aswaja Pressindo, Yogyakarta, 2012.

Peraturan Perundang-undangan

Undang-undang Dasar Negara

Kesatuan Republik Indonesia 1945

Undang-undang Nomor 39 Tahun

1999 Tentang Hak Asasi Manusia

Instruksi Presiden Nomor 1 Tahun

1991 Tanggal 10 Juni 1991. Tentang

Berlakunya Hukum Kompilasi

Hukum Islam

Direktorat Pembinaan Badan

Peradilan Agama Nomor 8/I/735

Tahun 1958 Menentukan 13 Fiqih yang menjadi pegangan Hakim Agama dalam menyelesaikan sengketa.

\section{Putusan Pengadilan}

Putusan Pengadilan Negeri

Semarang Nomor

3077/Pdt.P/2011/PN.Smg

Putusan Pengadilan Negeri Ungaran

Nomor 518/Pdt.P/2013/PN.Ung

\section{Karya Ilmiah}

Aswad, Muflika Nur Hajar. Kajian Yuridis terhadap Keputusan Pengadilan Negeri Tentang Penetapan Status kelamin seseorang yang berkelamin ganda (Ambiguos Genetalia), Skripsi Universitas Islam Negeri (UIN) Fakultas Hukum, Program Strata 1 (S1), Makassar, 2016.
Diningtria, Marisa Arsiwi, Sistem Kewarisan Khuntsa (Kelamin Ganda) menurut Hukum Waris Islam, Skripsi Universitas Lampung, Fakultas Hukum, Program Strata 1 (S1) : Bandar Lampung, 2017.

\section{Jurnal}

Diponegoro Law Journal Volume 6, Nomor 2, Tahun 2017 Website: http://www.ejournal-

S1.undip.ac.id/index.php/dlr/.

\section{Media Daring}

digilib.uin-suka.ac.id perubahan kelamin transeksual dalam kaitannya dengan sistem kewarisan islam digilib.unila.ac.id kelamin ganda menurut hukum waris islam 